\title{
THE FUNCTIONALITY PROFILE OF CHILDREN WITH AUTISTIC SPECTRUM DISORDERS (ASD) IN THE AZORES - COMMUNICATION, LEARNING AND AUTONOMY
}

\author{
Tânia Botelho ${ }^{1}$, Ana Matos ${ }^{1}$, Pilar Mota ${ }^{1}$, Bárbara Romão ${ }^{1}$, Suzana N. Caldeira ${ }^{2}$, \\ Isabel E. Rego ${ }^{3}$, Osvaldo Silva ${ }^{2}, \&$ Áurea Sousa ${ }^{4}$ \\ ${ }^{1}$ Centro de Desenvolvimento Infanto-Juvenil dos Açores Affiliation (Portugal) \\ ${ }^{2}$ Universidade dos Açores, CICS.UAc/CICS.NOVA.UAc (Portugal) \\ ${ }^{3}$ Universidade dos Açores, IVAR (Portugal) \\ ${ }^{4}$ Universidade dos Açores, CEEAplA (Portugal)
}

\begin{abstract}
Autism is a disorder of the neuro-development which is characterized by persistent difficulties in communication, speech, cognitive processes, social interaction and also by restrict interests and repetitive and stereotyped behaviours. This syndrome points to the importance of having trained and qualified staff, investing in physical and material resources, and searching for the most adequate answers to the educational needs of these children. Regarding the formal education, according to the vision of Universal Design for Learning (UDL), the educational approach should enhance not only the academic acquisitions but also the prognosis of the evolution of the clinical condition and of the functionality of children with Autistic Spectrum Disorders (ASD). Considering that UDL approach invests in flexible objectives, methods, materials and evaluation, to differentiate learning taking into account the needs of each pupil, it is important to know the perspectives of educators/teachers and parents/caretakers of children with ASD. These two groups have significant and additional information on these children potentialities. Educators/teachers and parents/caretakers of 121 children participated in this study. These children, aged 3-11 years old, live in the Autonomous Region of the Azores (ARA) and are enrolled in kindergarten and in primary schools, comprising 30 public schools, 8 private schools and 40 private institutions for social solidarity. Data were collected with a questionnaire (educators/teachers) and in an interview (parents/caretakers). Results suggest that there are different perspectives between the two groups, with educators/teachers viewing the functionality profile of these children as being more aggravated. The analysis of these different perspectives evidences the importance of the communication between these educational providers regarding the work developed by them in order to promote the functionality of children with ASD.
\end{abstract}

Keywords: Autism, functionality, family, school.

\section{Introduction}

\subsection{Autism spectrum disorder}

According to the American Psychiatric Association, Autism Spectrum Disorder (ASD) have as their etiology a central nervous system disorder whose manifestations affect a child's normative development. These symptoms may appear during the first 3 years of life, affecting interpersonal communication, social interaction, and interests, causing repetitive behavior and, therefore, impairing the daily functioning of children (APA, 2013). This clinical dysfunctionality is mainly reflected in resistance to common teaching methods and changes in routine. It may also involve cognitive impairment, changes in sleep patterns, difficulties in establishing eye and physical contact with others, difficulties in playing symbolic and "make-believe" games, fascination or obsession with specific subjects, hyper or hypersensitivity to auditory, visual and tactile stimuli, intense motor activity, among others (Lobo, 1998). To recognize all these characteristics is also to understand that children with ASD need differentiated educational responses and that providing the necessary support simultaneously promotes the acquisition of learning and optimizes communication and socialization skills (Pereira, 2008). In 2001, the World Health Organization made it possible to understand the ASD through a biopsychosocial and integrated model of human functionality and disability - the International Classification of Functioning, Disability and Health - Children and Youth (ICF-CY). This Classification served the purpose of standardizing the language on the subject and allowed educational, health, and rehabilitation professionals to describe the functionality profiles of children up to 18 years of age by assessing development and behavior in dimensions such as communication, learning, and autonomy (CPDEC, sd). 


\subsection{Communication, learning and autonomy in autism spectrum disorder}

Research unanimously refers to changes in communication and language as the main factors of ASD and as having a strong impact on the quality of these individuals' social interaction and behavior (Fernandes, 1994). This communication deficit also reflects a severity spectrum that can range from the total absence of communication to fluent language (Oliveira, 2005). However, what characterizes the communication profile of individuals diagnosed with ASD, even the high functioning ones, is the existence of deficits in the level of social pragmatics and in the comprehension of language as a whole. The delay in the development of expressive language, and even its absence, is one of the main reasons for clinical referral.

The learning profile of children with ASD is related to the various cognitive abilities that these children may have, ranging from deep mental disability to higher intelligence (Abreu, 2013). Children with ASD may be more frequently impaired in four specific areas of cognition: imitation, social interaction, play and skills, and ability to develop "theory of mind" skills (Brown \& Whiten, 2000). According to Ortiz (2005), ASD children have cognitive rigidity, that is, difficulties in adapting to new learning. Given this characteristic, and in order to facilitate learning processes, these children benefit from learning based on concrete and contextual stimuli (Mota, 2008). The resistance to change and new learning also has its origin in the children's limited imaginative capacity and symbolic play, what can have negative repercussions on the development of conceptual structures and even on the ability of these children to solve problems of a symbolic nature, such as calculus, reading and writing (Hewitt, 2006).

Autonomy is a process that begins in the early years of the individual's life and develops throughout life (Silva, 2015). This ability for an individual's personal, domestic and social performance in their environment is one of the most important achievements in attaining their social independence. Thus, it is essential to evaluate the adaptive behavior that allows characterizing this domain of the personal development of children with ASD (Oliveira, 2005). According to Oliveira (2005), results from the application of the Griffiths Mental Development Scale in children with ASD show low rates in the areas of language and practical reasoning and higher rates in the areas of achievement, global motor skills and social staff (autonomy). However, individuals with ASD have a significantly lower environmental adaptive capacity when compared with groups of other individuals without ASD (Oliveira, 2005).

\subsection{The contribution of the Universal Design to Learning (UDL) in the learning of students with Autism}

This methodology has been recognized as an asset in supporting the inclusion of students with special educational needs, such as students with ASD. Denning and Moody (2014) report that the principles of the UDL methodology are very valid responses in adapting the classroom environment, as these students may find it difficult to maintain attention, filter out unnecessary information and the ability to change. the attentional focus. Another concern to address concerns the need to adapt the presentation of content considering the limitations that these students may feel at the level of information processing or even regarding the requirement for cognitive flexibility (Goldstein, Johnson \& Mineshew, 2001). The concept of self-involvement, considered of great importance in the UDL, is also one of the main objectives to consider when including a student with ASD in the classroom, especially since routines are an important factor for the adequacy of their behavior and for the consolidation of learning (Mancil \& Pearl, 2008).

According to Mcleskey and Wldron (2007), effective inclusion fits into the UDL methodology given that, as this theory predicts, support for students with special educational needs in the classroom should be discrete. That is the only way they can feel naturally belonging to a school context. According to these authors, teachers should use supports and teaching methods that are effective for all students.

Ultimately, and from the perspective of Denning and Moody (2014), the application of UDL in pupils with ASD may represent an advance in improving school achievement as this approach promotes understanding, independence and performance of these children. The same authors point out that the principles of UDL include the use of supports for routines and procedures, the preparation / anticipation of material and subjects that can assist in the selection of content that constitutes meaningful learning related to skills and previous knowledge of the students; also the use of visual clues (such as symbols or photos) and other tools that increase the forms of representation, and the use of structured tools for the analysis and expression of content; finally, as a primary advantage, to consider and value the interests of the student, with a view to enhancing their involvement and active participation.

\subsection{Importance of school-family articulation}

In addition to a curriculum that considers the needs of children with ASD and values their interests, the articulation between the School and the family system is equally relevant. Success in acquiring the different stages of the process of communication, learning, and autonomy of a child ASD is closely related to their skills, but also with the attitude and skills of their family members to face of this disturbance (Gomes, 2012/13). The birth and growth of a child with neurodevelopmental problems 
encourage parents to accept their condition, and to seek to apply the responses that best fit their child's real needs and abilities (Gomes, 2012/13). Likewise, according to Gomes (2012/13), it is of great importance that parents share information about the child to school so that the institution meets the necessary conditions for the promotion and enhancing their skills. Similarly, it is essential that these families, as well as schools, are aware of the importance of implementing strategies that enhance the development of communication, learning, and autonomy, and where students perform domestic tasks, solve problems and are stimulated in negotiation skills as a way of promoting responsibility and self-control (Silva, 2015). A close sharing relationship between family and school is a fundamental factor for the good prognosis in the evolution of the functionality of children with neurodevelopmental disorders (Martins, Acosta \& Machado, 2016).

\section{Methodology}

The target population comprises 172 children with a diagnosis of ASD. It was used a sample of 121 children whose parents agreed to participate in the study, mostly boys (82\%), the average age of 6 and a half years old. Half of the children have mildly severe ASD, 32\% a moderate degree, $4 \%$ a severe degree, and $14 \%$ did not report.

The data were collected through structured interviews, based on a literature review on autism, instruments used in the identification and characterization of autism, and the variables of the International Classification of Functioning, Disability, and Health (ICF) in the domain of communication, learning, and autonomy. The interview with caregivers was composed of five dimensions: i) personal data of the child; ii) socio-family characterization; iii) clinical history; iv) functionality and participation profile; v) impact of ASD on the family. The interview with educators comprised three dimensions: i) data from the institution; ii) student's personal data; and iii) functionality and participation profile.

This study was previously submitted to the Regional Directorate of Education and to the Ethics Committee of the University of the Azores, having been issued by both entities in favour of its realization. The Board of Directors/Coordination of each of the educational institutions was then contacted in order to obtain their cooperation. The parents of the children were also auscultated, through the respective educational institutions, who explained the nature and purpose of the study. Families who agreed to collaborate and consented to the consultation of their children's Individual Educational Programs (IEP) signed their Informed Consent. All collected data were entered into IBM SPSS Statistics, constituting a database with 121 rows, each of which refers to each case of ASD. Data were analyzed using some methods of Descriptive Statistics.

\section{Presentation and analysis of results}

Tables 1, 2 and 3 present a summary of the results regarding the functionality profile of children with ASD, regarding, respectively, Communication, Learning and Application of Knowledge and Autonomy (self-care), from the perspective of educators/teachers and of parents.

The observation of Table 1 indicates that educators/teachers, compared to parents, detected more difficulties in terms of items related to Communication.

Table 1. Communication: Comparison between the two perspectives.

\begin{tabular}{|l|c|c|}
\hline Communication & $\begin{array}{l}\text { Does not do it alone/Some kind of } \\
\text { disability } \\
\text { "School" Perception }\end{array}$ \\
\hline $\begin{array}{l}\text { Communicate and receive oral } \\
\text { messages }\end{array}$ & 88,2 & Family Perception \\
\hline $\begin{array}{l}\text { Communicate and receive nonverbal } \\
\text { messages }\end{array}$ & 87,5 & 47,9 \\
\hline Speak & 82,4 & 57,9 \\
\hline Produce nonverbal messages & 86,4 & 52,1 \\
\hline Conversation & 92,1 & 57,9 \\
\hline Discussion & 91,5 & 63,6 \\
\hline $\begin{array}{l}\text { Use of communication devices and } \\
\text { techniques }\end{array}$ & 73,4 & 62,0 \\
\hline
\end{tabular}

The biggest difference between both perspectives lies in the task of "Communicate and receive oral messages" and the smallest differences lie in the tasks of "Conversation" and "Produce nonverbal messages". However, in both cases, school elements perceive greater difficulties.

The observation of Table 2 indicates that educators / teachers, compared to parents, detected more difficulties in terms of aspects related to Learning and Knowledge Application. 
Table 2. Learning and Knowledge Application: Comparison between two perspectives.

\begin{tabular}{|l|c|c|}
\hline \multirow{2}{*}{$\begin{array}{l}\text { Learning } \text { Knplication } \\
\text { Apowledge }\end{array}$} & $\begin{array}{l}\text { Does not do it alone/Some kind of } \\
\text { disability } \\
\text { "School" Perception }\end{array}$ & Family Perception \\
\hline Observe & 67,0 & 19,0 \\
\hline Listen & 59,8 & 20,7 \\
\hline Imitate & 75,8 & 22,3 \\
\hline Learn by Interacting with Objects & 71,4 & 20,7 \\
\hline Acquire information & 80,0 & 40,5 \\
\hline Acquire language & 82,7 & 50,4 \\
\hline Rehearse (Repeat) & 77,3 & 52,1 \\
\hline Think & 89,0 & 33,9 \\
\hline Solve Problems & 93,3 & 68,3 \\
\hline Make Decisions & 91,4 & 54,5 \\
\hline
\end{tabular}

The biggest differences between both perspectives are in the items "Think" and "Imitate" and the smallest differences are in the items "Solve Problems" and "Rehearse". However, there is consensus between both parts concerning the most significant difficulties located in the area of problem solving and decision making.

The autonomy skills were analysed in the light of self-care. The observation in Table 3 indicates that this is the area of greatest consensus and there are items, such as "Dress up", in which there are no divergence between school and family.

Table 3. Self-care: Comparison between both perspectives.

\begin{tabular}{|l|c|c|}
\hline \multirow{2}{*}{ Self-care } & $\begin{array}{l}\text { Does not do it alone/Some kind of } \\
\text { disability }\end{array}$ & \\
\cline { 2 - 3 } & "School" Perception & Family Perception \\
\hline Take care of body parts & 57,4 & 69,4 \\
\hline Care related to excretion processes & 51,9 & 58,7 \\
\hline Dress up & 60,5 & 60,3 \\
\hline Eat & 50,0 & 28,9 \\
\hline Drink & 31,7 & 17,5 \\
\hline Take care of their own health & 50,0 & 62,0 \\
\hline
\end{tabular}

The results of the present study prove the existence of a very different perspective about the skills of children with ASD, by caregivers and educators, mainly in the fields of Communication and Learning and Application of Knowledge. Although both perspectives identify limitations regarding the functionality of children with ASD, it is clear that caregivers have a more optimistic view of their children's skills. The average age of children in the sample, 6 years old, may partially explain these findings. It might be not easy for educators to find and implement teaching and interaction methodologies that overcome ASD's limitations

This brings us to the importance of practicing a teaching methodology such as UDL that enables these children to demonstrate their knowledge through multiple forms of expression and motivates them to achieve curriculum learning goals effectively and with significant involvement and participation. The positive results of this involvement in learning could contribute to cooperative work and closer communication between school and family, encouraging more realistic and objective expectations regarding the empowerment of children with ASD. In addition, it is important to increase training opportunities for professionals in various areas to improve their performance regarding the ASD.

\section{Conclusion}

The present work aimed to perform a characterization of the functionality profile of children with ASD in AAR, according to the perspectives of their educators / teachers and families. Children with ASD usually have significant difficulties in the areas of communication, socialization and behaviors. As such, it is essential to know not only the level of these limitations, but above all their areas of interest and their skills so that staff and family members can be successful in carrying out their mission. Pedagogical assessment and teaching methodologies with an emphasis on the active and motivated participation of these students can, according to current literature, contribute more efficiently to the optimization of these children as autonomous students and future youth and adults with a proactive role in society. As limitations of the study, we identify the information collection instrument itself, which is used as an evaluation instrument in school contexts, and did not allow characterizing the sample profile regarding its 
areas of interest and motivations. Another weakness of this study was the failure to collect information regarding the methodology, strategies and learning support materials used by schools. Future research in this domain should improve data collection methods and contribute to optimizing the response in the areas of training, consulting and intervention within the scope of the ASD.

\section{References}

Abreu, C. C. (2013). Avaliação de alunos com perturbações do espectro do autismo em unidades de ensino estruturado do $1^{\circ}$ ciclo. Tese de mestrado, Instituto Superior de Educação e Ciências, Lisboa, Portugal.

American Psychiatric Association. Manual Diagnóstico e Estatístico de Transtornos Mentais: DSM-5 ( $5^{\mathrm{a}}$ ed) (2013). Porto Alegre: Artmed.

Brown, J. \& Whiten, A. (2000). Imitation, theory of mind and related activities in autism. Autism, 4 (2), $185-204$.

CPDEC (s.d.). Classificação Internacional de Funcionalidade, Incapacidade e Saúde: Versão para Crianças e Jovens. Porto: Faculdade de Psicologia e Ciências da Educação da Universidade do Porto.

Denning, C. B. \& Moody, A. K. (2013). Supporting Students with Autism Spectrum Disorders in Inclusive Settings: Rethinking Instruction and Design. Electronic Journal for Inclusive Education, $3(1)$.

Fernandes, F. (1994). A questão da linguagem em Autismo Infantil: uma revisão crítica da literatura. Revista Neuropsiquiatria da Infância e da Adolescência, 2 (3), 5-10.

Goldstein, G., Johnson, C. R. \& Minshew, N. J. (2001). Attentional Processes in Autism. Journal of Autism and Developmental Disorders, 31 (4), 433-440.

Gomes, M. (2012/13). Envolvimento familiar e autonomia na criança com Síndrome de Asperger, Porto. Retirado do Repositório da Escola Superior de Educação de Paula Frassinetti.

Hewitt, S. (2006). Compreender o Autismo - Estratégias para alunos com Autismo nas escolas regulares. Porto: Porto Editora.

Lobo, C. (1998). Perturbações do Espectro do Autismo: do Conceito à Intervenção. Trabalho final do Curso de Estudos Superiores Especializados em Educação Especial - Problemas Graves de Motricidade e Cognição, apresentado à Escola Superior de Educação de Coimbra.

Mancil, G. R., \& Pearl, C. E. (2008). Restricted interests as motivators: Improving academic engagement and outcomes of children on the autism spectrum. Tea-ching Exceptional Children Plus, 4(6), $1-15$

Martins, M. F. A., Acosta, P. C., \& Machado, G. (2016). A parceria entre escola e família de crianças com transtorno do espectro do autismo. Caderno de Pesquisas em Educação, 43, 59-71.

Mota, M. (2008). Avaliação da maturação percepto-cognitiva e do comportamento motor em crianças com transtorno autista: Indicações ao trabalho do educador. Revista Electrónica de Investigación y Docencia, 1, 71-98.

Oliveira, G. G. (2005). Epidemiologia do autismo em Portugal: Um estudo de prevalência da perturbação do espectro do autismo e de caracterização de uma amostra populacional de idade escolar. Tese de doutoramento, Faculdade de Medicina de Coimbra, Portugal, Coimbra.

Ortiz, F. (2005). Autismo. Gaceta Médica de México, 141 (2), 143-147.

Pereira, F. (2008). Unidades de Ensino Estruturado para Alunos com Perturbações do Espectro de Autismo - Normas Orientadoras. Lisboa: Ministério da Educação - DGIDC.

Silva, R. M. C. (2015). O papel da família no desenvolvimento da autonomia do portador de sindroma de Asperger. Escola Superior de Educação João de Deus, Lisboa, Portugal. 